\title{
A case of bilateral Chikungunya neuroretinitis
}

\author{
Akshay Gopinathan Nair • Jyotirmay Biswas • \\ Muna P. Bhende
}

Received: 15 July 2011 /Accepted: 17 August 2011 /Published online: 1 September 2011

(C) The Author(s) 2011. This article is published with open access at SpringerLink.com

Keywords Neuroretinitis · Retinitis · Chikungunya

A 65-year old Asian-Indian presented with a month-old history of sudden, painless diminution of vision in both eyes (OD-20/200, OS-20/400). A nondiabetic, he had no history of hypertension or tuberculosis. He gave a history of fever and malaise associated with joint pain 1 week prior to onset of ocular symptoms. Left eye showed $2+$ cells in the anterior chamber, while the right eye was quiet. No afferent pupillary defect was noted. Dilated fundus examination revealed neuroretinitis, cotton wool spots, hemorrhages, and a grade 2 vitreous haze in both eyes (a). Investigations for antinuclear antibodies, C-reactive protein, HIV, hepatitis B and C, Widal, Mantoux and QuantiFERON TB Gold were negative. The total leukocyte count and ESR were raised. Serum angiotensin-converting enzyme levels as well as platelet count were within normal limits. Reverse transcription polymerase chain reaction assay for Chikungunya performed on the patient's serum revealed 358 copies of RNA/ $\mu$ l (b). A diagnosis of Chikungunya neuroretinitis was made, and the patient was treated with oral steroids and oral acyclovir $800 \mathrm{mg}$ five times a day for 3 weeks, after which partial resolution was noted (c).

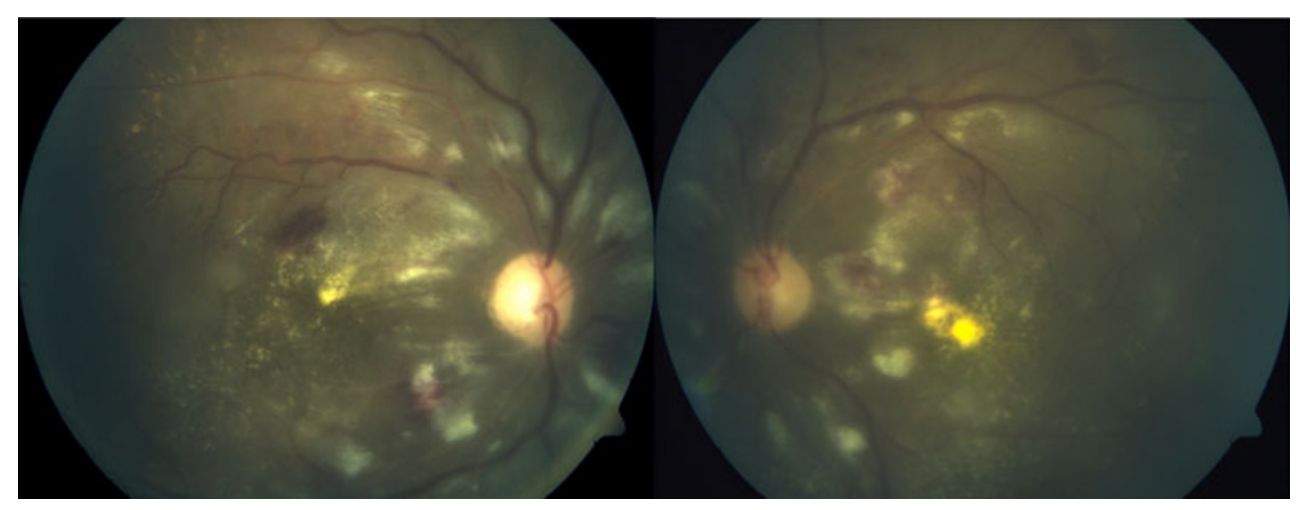

A. G. Nair $(\bowtie) \cdot J$. Biswas $\cdot$ M. P. Bhende

Sankara Nethralaya, A Unit of Medical Research Foundation,

18 College Road, Nungambakkam,

Chennai 600006 Tamil Nadu, India

e-mail: akshaygn@gmail.com

J. Biswas

e-mail: drjb@snmail.org

M. P. Bhende

e-mail: drmpb@snmail.org 

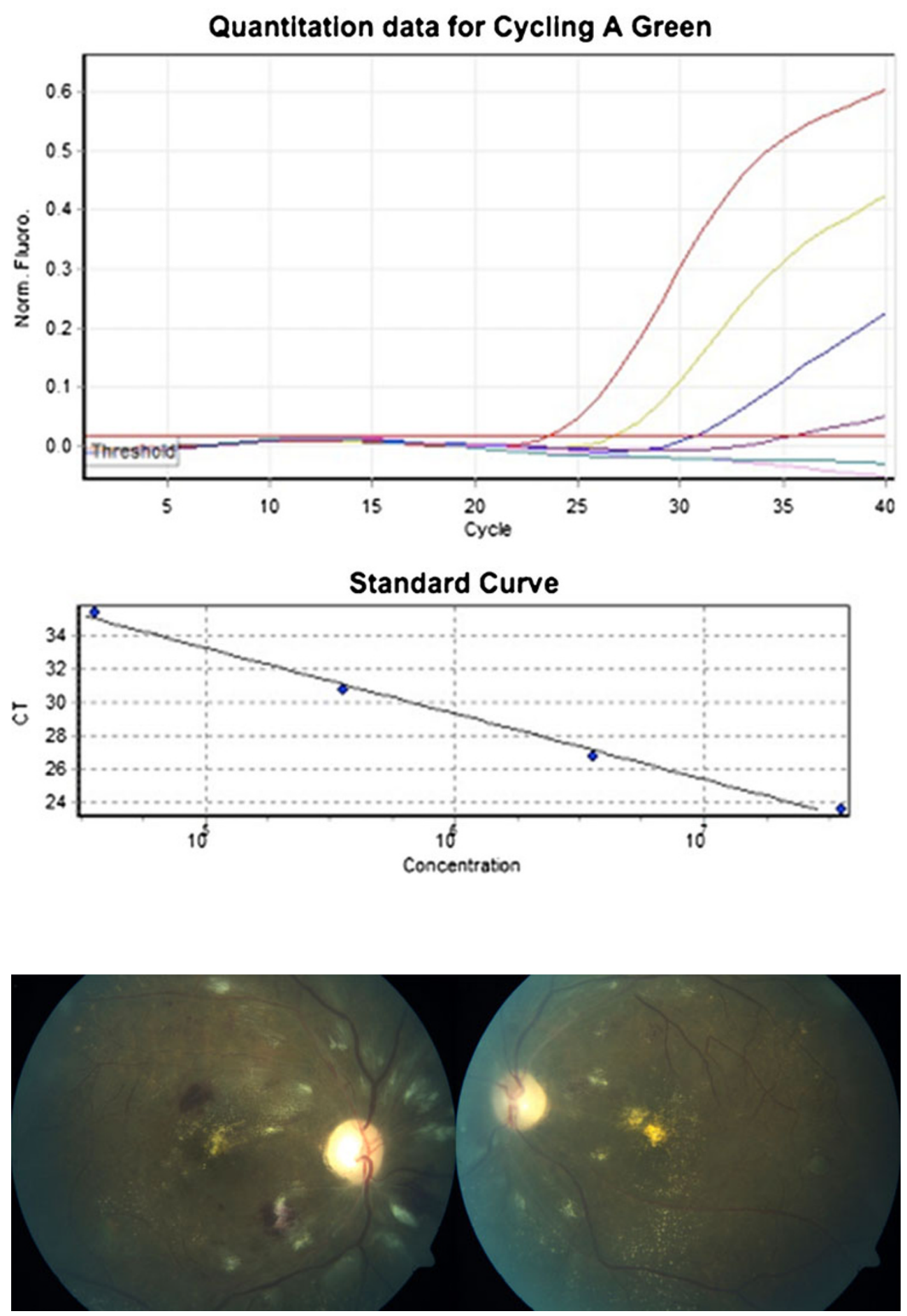

Financial disclosures None.

Possible conflict of interest None.
Open Access This article is distributed under the terms of the Creative Commons Attribution License which permits any use, distribution and reproduction in any medium, provided the original author(s) and source are credited. 